\title{
Elephantiasis nostras verrucosa
}

\author{
Halis Kaan Akturk, Maryam Gbadamosi-Akindele
}

Department of Internal Medicine, Creighton University Medical Center, Omaha, Nebraska, USA

\section{Correspondence to} Dr Halis Kaan Akturk, kaanakturk@yahoo.com

Accepted 9 March 2014

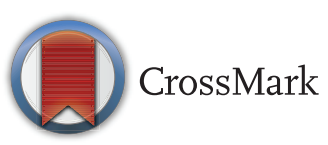

To cite: Akturk HK, Gbadamosi-Akindele M. BMJ Case Rep Published online: [please include Day Month Year] doi:10.1136/ bcr-2013-200363

\section{DESCRIPTION}

A 63-year-old obese man presented with worsening lower leg oedema, fever and chills. Physical examination revealed non-pitting oedema and hyperkeratotic papulonodules with a verrucose appearance in lower extremities, especially at posterior tibial side (figure 1). Oedema sites were warm and red. $\mathrm{He}$ had a history of colon cancer treated 8 years ago with surgery and radiotherapy to the lower abdomen. Chronic lymphoedema developed after radiotherapy in both lower extremities (figure 2). He had multiple hospital admissions due to cellulitis related to lower leg oedema. He was treated with intravenous antibiotics and discharged with recommendations of elevation of the limbs and wound care.

Elephantiasis nostras verrucosa is a rare, disfiguring complication of longstanding chronic lymphoedema. ${ }^{1}$ It is characterised by marked oedema of the affected extremity, generalised thickening and lichenification of the skin. ${ }^{2}$ Disruption of the lymphatic system after trauma, surgery or radiation is the most common cause of chronic lymphoedema. Recurrent soft tissue infections also induce fibrosis and worsen the condition. ${ }^{3}$ Congenital, traumatic or surgical disruption of lymphatic vessels, venous stasis, radiation, neoplastic obstruction, portal hypertension, obesity and congestive heart failure are the precipitating factors of this disease. ${ }^{2}{ }^{3}$ The diagnosis is based on the history and the peculiar skin changes. Treatment options include use of elastic bandages, pneumatic stockings, mechanical massage, oral retinoids and surgery. The goal of the therapy is to re-establish function and to reduce physical

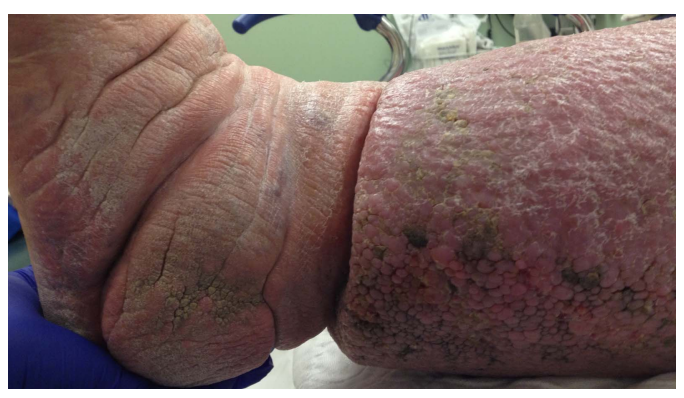

Figure 1 Left ankle and posterior tibial area.

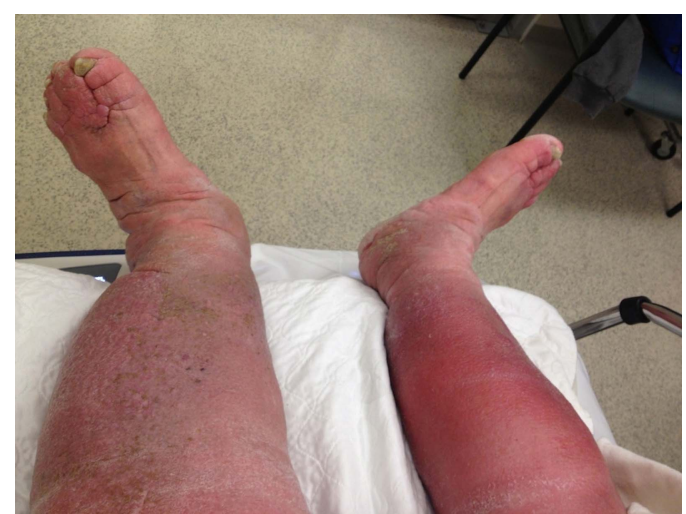

Figure 2 Chronic lymphoedema in lower extremities.

disability. Oral retinoids were used successfully in some case series. For refractory cases, microsurgical lymphovenous anastomosis can be used. Amputation should be the last option.

\section{Learning points}

- Elephantiasis nostras verrucosa is a serious complication of longstanding chronic lymphoedema.

- Soft hyperkeratotic verrucose appearance distinguishes this lesion from the oedematous site.

- Prompt diagnosis is needed to prevent disability and recurrent infections.

Contributors Both the authors were actively involved in patient care and the preparation of the manuscript.

Competing interests None.

Patient consent Obtained.

Provenance and peer review Not commissioned; externally pee reviewed.

\section{REFERENCES}

1 Sisto K, Khachemoune A. Elephantiasis nostras verrucosa: a review. Am J Clin Dermatol 2008;9:141-6.

2 Vaccaro M, Borgia F, Guarneri F, et al. Elephantiasis nostras verrucosa. Int J Dermatol 2000;39:764-6.

3 Yoho RM, Budny AM, Pea AS. Elephantiasis nostras verrucosa. J Am Podiatr Med Assoc 2006;96:442-4. 
Copyright 2014 BMJ Publishing Group. All rights reserved. For permission to reuse any of this content visit http://group.bmj.com/group/rights-licensing/permissions.

BMJ Case Report Fellows may re-use this article for personal use and teaching without any further permission.

Become a Fellow of BMJ Case Reports today and you can:

- Submit as many cases as you like

- Enjoy fast sympathetic peer review and rapid publication of accepted articles

- Access all the published articles

- Re-use any of the published material for personal use and teaching without further permission

For information on Institutional Fellowships contact consortiasales@bmjgroup.com

Visit casereports.bmj.com for more articles like this and to become a Fellow 